\title{
DEVELOPMENT AND IMPROVEMENT OF SWITCHING STANDS OF HIGH-VOLTAGE LUE MODULATORS
}

\author{
V.I. Beloglazov, O.I. Kosoy, V.A. Mats, V.P. Romasko, I.A. Chertischev, V.Yu. Tytov, \\ I.O. Chaika, Yu.A. Titarenko, Yu.D. Tur \\ National Science Center "Kharkov Institute of Physics and Technology”, Kharkiv, Ukraine \\ E-mail: ch.igor@kipt.kharkov.ua
}

The results of the development, operation and improvements of switch racks are presented. Particular attention is paid to the control and protection systems of both the thyratrons themselves and the control units of the switches. The main characteristics and the degree of reliability of switching racks and thyratrons of various types are compared. The development and implementation of switching racks based on six types of thyratrons was carried out: TGI1-1000/25, TGI1-2500/35, TGI1-5000/50, TGI1-5k/50 (Russia), TGI1-2500/50 (Ukraine) and CX 1525 A (England).

PACS: $2917+\mathrm{w}$

\section{INTRODUCTION}

The switch is an important part of the installation. It has a number of requirements for maximum operating voltage, maximum switched current, average current, etc. Therefore, the choice of the switch and its components largely determines the reliability of the installation. $[1,2]$ The selected thyratron should have characteristics that meet the technical requirements of the technological accelerator.

Hydrogen thyratrons (three-electrode or fourelectrode) are used as a commutator in many technological installations. They are designed to form short high voltage pulses at high currents in the load. Hydrogen thyratron is usually metal - ceramic version has a heated cathode and a control grid. Typical pulse parameters: duration is nano or microseconds, voltage is $5 \ldots .50 \mathrm{kV}$, current is from $50 \mathrm{~A}$ to $15 \mathrm{kA}$, repetition rate is $0.2 \ldots 100 \mathrm{kHz}$. The pulses are formed by quickly connecting the load to the energy storage (capacitor that sets the long line), which is completely discharged dur- ing the pulse. Connection is made by a thyratron upon receipt of a relatively low-power voltage pulse at the control electrode. Modulators on hydrogen thyratrons have a number of positive qualities. They are simple in design and have high efficiency.

High-voltage modulators of linear electron accelerators of the NSC KIPT are based on a standard linear circuit with a resonant charge of the PFN and its subsequent discharge through a thyratron switch to a pulse high-voltage power transformer of amplifying klystrons. In operating mode, the switching rack should provide switching currents of up to $3 \mathrm{kA}$ with anode voltage of up to $30 \mathrm{kV}$, transmission frequency of up to $300 \mathrm{~Hz}$ and pulse duration of up to $6 \mu \mathrm{s}$ with high stability and long-term operation.

Subject to the technical requirements for operation, most thyratrons far exceed the guaranteed operating time [3]. However, most of these thyratrons have exhausted their resources.
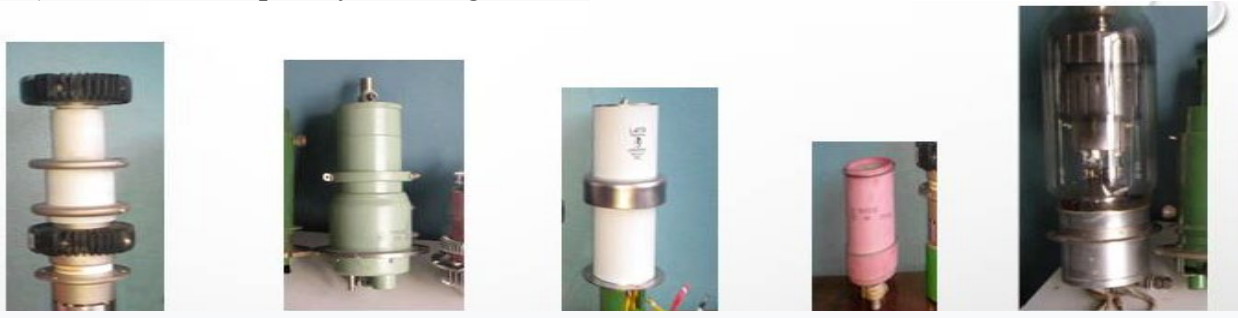

Fig. 1. Thyratrons used in modulators RC "Accelerator"

Table 1

The main technical characteristics of thyratrons operating in modulators RC "Accelerator"

\begin{tabular}{|c|c|c|c|c|c|c|c|c|c|c|}
\hline \multirow{2}{*}{$\begin{array}{l}\text { Parameter name, } \\
\text { units of meas- } \\
\text { urement }\end{array}$} & \multicolumn{2}{|c|}{ CX1525a } & \multicolumn{2}{|c|}{ TGI-2500/50 } & \multicolumn{2}{|c|}{ L-4174 } & \multicolumn{2}{|c|}{ TGI-1000/25 } & \multicolumn{2}{|c|}{ TGI-2500/35 } \\
\hline & Rating & Actual & Rating & Actual & Rating & Actual & Rating & Actual & Rating & Actual \\
\hline $\begin{array}{l}\text { Pulse anode } \\
\text { voltage, } \mathrm{kV}\end{array}$ & 50 & 45 & $10 \ldots 50$ & 45 & 33 & 20 & $5 \ldots 25$ & $5 \ldots 25$ & 35 & 25 \\
\hline $\begin{array}{l}\text { Pulse anode } \\
\text { current, } \mathrm{kA}\end{array}$ & 5 & 2 & 2.5 & 2 & 2 & 2 & 1 & 0.9 & 3.5 & 2 \\
\hline $\begin{array}{l}\text { Average anode } \\
\text { current, A }\end{array}$ & 5 & 3 & 4 & 3 & 4 & 3 & 1 & 0.7 & 2.5 & 2 \\
\hline Frequency, $\mathrm{Hz}$ & 2500 & 200 & 400 & 200 & 500 & 200 & 700 & 50 & 300 & 200 \\
\hline Cooling & \multicolumn{2}{|c|}{ Air 5 cube $/ \mathrm{min}$} & \multicolumn{2}{|c|}{ Water $31 / \mathrm{min}$} & \multicolumn{2}{|c|}{ Air 5 cube/min } & \multicolumn{2}{|c|}{ Air $1 \mathrm{cube} / \mathrm{min}$} & \multicolumn{2}{|c|}{ Air 3 cube/min } \\
\hline
\end{tabular}




\section{THIRATRONS IN RESEARCH COMPLEX «ACCELERATOR» MODULATORS}

In the switch racks of modulators of technological accelerators, various types of thyratrons were used.

Fig. 1 shows the appearance of thyratrons operating in modulators and Table 1 with their main parameters. The figure shows that during the operation of the switches, not one of their permissible parameters was exceeded.

Widespread use in the facilities of RC "Accelerator" was received by thyratrons CX1525A. A distinctive feature of this thyratron is the need for control over two grids, and deuterium filling. In the current modulators, the MA2709 E2V launch unit, as well as single-channel launch units manufactured at the NSC KIPT, are used to start the CX1525A two-grid thyratron.

The disadvantage of this switch is the need to run on two grids. To do this, you need to create separate blocks that meet the startup parameters of this switch.

Fig. 2 signals from the MA2709A launcher on thyratron grids with and without thyratron glow are shown.

The trigger unit generates signals with an amplitude of $500 \ldots 1000 \mathrm{~V}$ with a negative offset of $-100 \mathrm{~V}$ to the upper grid. The pulse delay on the second grid of the thyratron relative to the first is $0.5 \mu \mathrm{s}$.

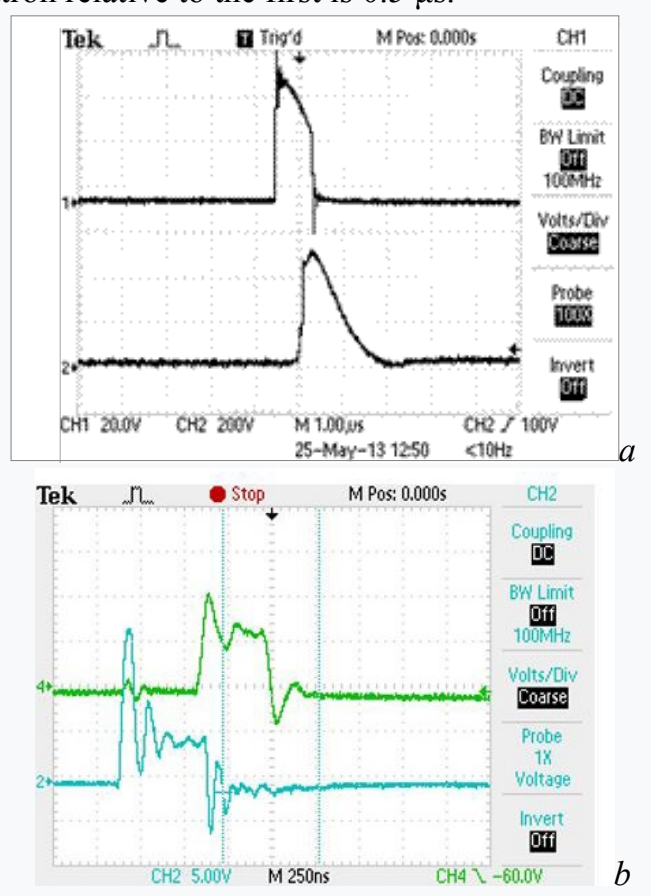

Fig. 2. Voltage pulses on thyratron grids without a glow (a) and with a glow (b)

In Fig. 2,b Oscillograms of pulses on the thyratron grids with the glow on are shown. The figure shows how the pulses change during the heating of the thyratron. So, in the operating mode, a surge of $\sim 300 \mathrm{~ns}$ with an amplitude of $\sim 1000 \mathrm{~V}$ occurs on the pulse of the first grid. Thus, the rise rate of the voltage pulse on the grid increases, which is $-10 \mathrm{kV} / \mu \mathrm{s}$. The momentum on the second grid decreases in amplitude in the positive part, so the second grid works at a negative bias. This allows you to reduce the deionization time after discharge through the switch, which is useful when working at high frequencies.

Fig. 3 shows the appearance of such a thyratron on a switch rack.

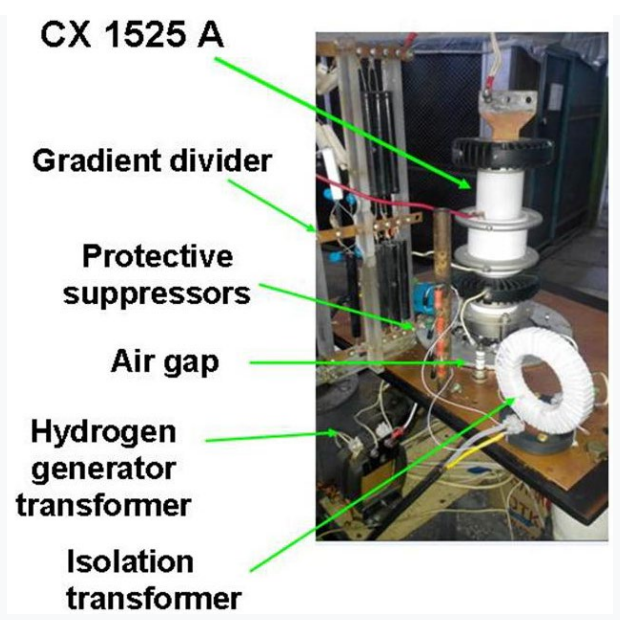

Fig. 3. Tiratron CX1525A on a switch rack

To protect the launch units, their earth is galvanically isolated from the thyratron cathode using isolation transformers. Also, protective suppressors are used as protection to limit the current flowing to the elements of the starting block circuit.

For the reliability of the switch, a gradient divider is used, having a resistive and capacitive (for fast rise times) parts. Gradient divider allows you to distribute the anode potential on the surface of the thyratron, which avoids breakdown on the surface of the thyratron and makes its operation more stable.

When the commutator racks are operating, breakdown along the thyratron surface or breakdown from the cathode to the grid is possible (Fig. 4, Table 2). Protective arresters are used to prevent this. Also, in the thyratron grid circuit, it is necessary to use limiting resistances that allow you to set the current value of the grids according to the technical operating conditions.

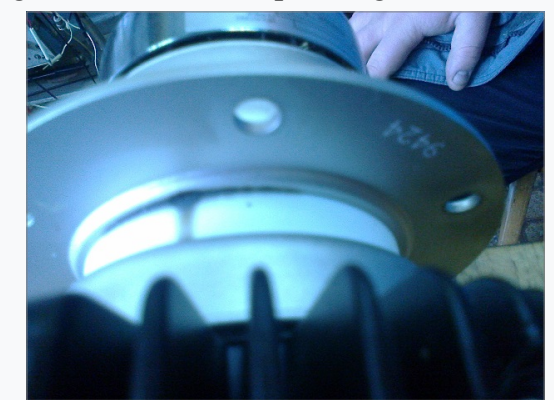

Fig. 4. Breakdown on the thyratron grid

Table 2

The operating time of thyratrons $C X 1525 \mathrm{~A}$ in modulators RC "Accelerator"

\begin{tabular}{|c|c|c|}
\hline$N$ & $\begin{array}{c}\text { Running } \\
\text { hours, } \\
\text { Thousand } \\
\text { hours }\end{array}$ & Note \\
\hline 9419 & 4.5 & Verification needed \\
\hline 9207 & 4.05 & Verification needed \\
\hline 9282 & 5.7 & Verification needed \\
\hline 9327 & 3.45 & Verification needed \\
\hline 9206 & 2 & No start \\
\hline 9421 & 5.55 & Conductive from anode to cathode \\
\hline 9521 & 5.5 & Conductive from anode to cathode \\
\hline 9424 & 4.05 & Conductive from anode to cathode \\
\hline 9005 & 2.05 & Shorted glow \\
\hline
\end{tabular}


Fig. 5 illustrated the appearance and triggering pulses on the networks of thyratrons TGI 1 1000/25. To start the thyratron, it is necessary to have a pulse with an amplitude of $600 \ldots 1000 \mathrm{~V}$, with a duration of $2 \ldots 4 \mu \mathrm{s}$.

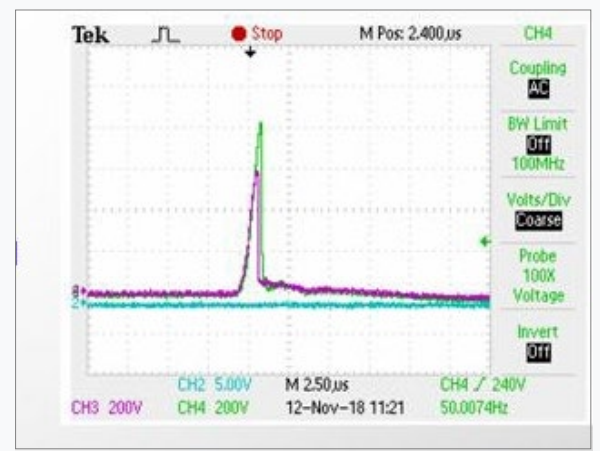

Fig. 5. Impulses of thyratron launch TGI1 1000/25

The disadvantages of this type of thyratrons include the need to use 3 thyratrons in one switch rack. Therefore, for a stable launch, it is necessary to select modes for both a single thyratron and for working in a group.

The advantages of this type of thyratrons are their relative cheapness and the availability of backup switches. With the right selection of parameters, these switches showed good reliability in operation (Fig. 6).

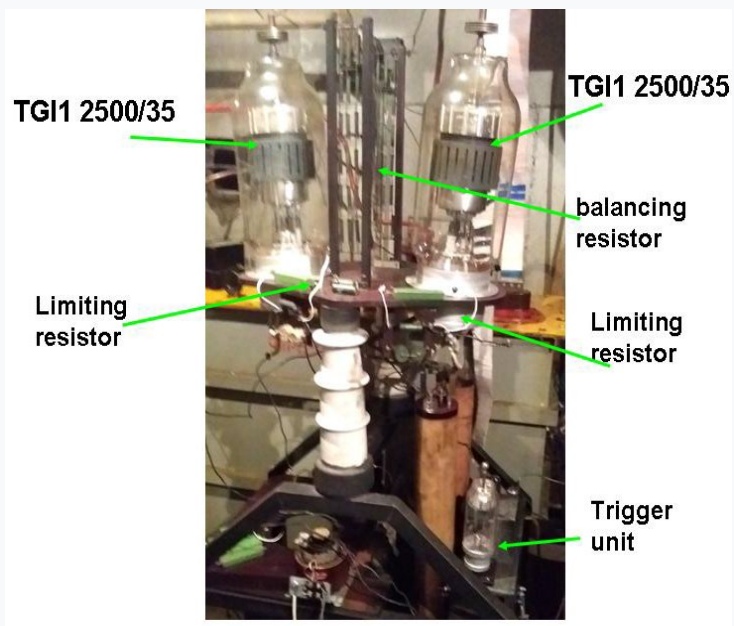

Fig. 6. TGI12500/35 thyratrons on a switch rack

Also in experimental installations and small accelerators TGI1 2500/35 switches are used. The TGI12500/35 thyratrons proved to be quite reliable and unpretentious in operation. They do not require special cooling. The disadvantages include the fact that for reliable operation in the switch rack of a technological accelerator, it is necessary to use at least 2 thyratrons connected in series. That is, for each thyratron, it is necessary to select its own mode for a reliable start. Given the fact that many 0of these switches have long exhausted their resources, it is quite difficult to do this. The advantage is that they are available and choosing them to work on test benches is a feasible task.

A large number of TGI12500/35 thyratrons were tested. Some of them managed to be reanimated and put into operation at various technological accelerators and test benches.

The most widely used in modulators of powerful linear accelerators are ceramic-metal thyratrons TGI1 2500/50 (Fig. 7).

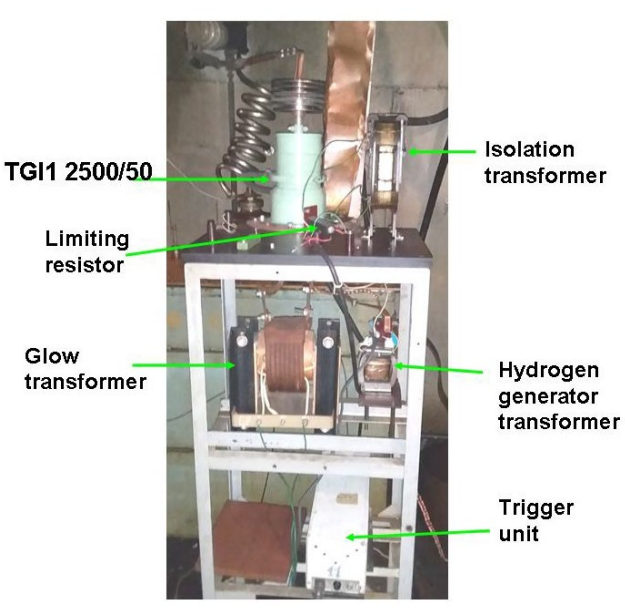

Fig. 7. TGI12500/50 thyratrons on a switch rack

Their advantages include relative ease of installation. Unlike the two-grid thyratron CX1525A, one trigger unit manufactured at the NSC KIPT is used for connection.

In addition, this switch is similar in parameters to the CX1525A thyratron, that is, they can be used one at a time in the switch rack of linear accelerator modulators.

These thyratrons works in technological accelerators EPOS, KUT-1, LUE-10. Their operating time is $\sim 6$ thousand hours or more.

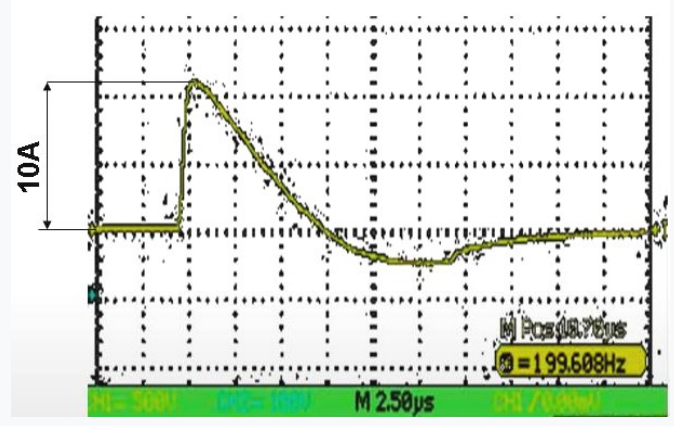

Fig. 8. Current pulse on the grid of the thyratron TGI12500/50

Fig. 8 shows the current pulse on the grid of the TGI1 2500/50 thyratron. The correct selection of the parameters of the starting circuit (starting block, limiting resistance, isolation transformer) of the switches allows you to select the required values of the grid current, and therefore increase their resource.

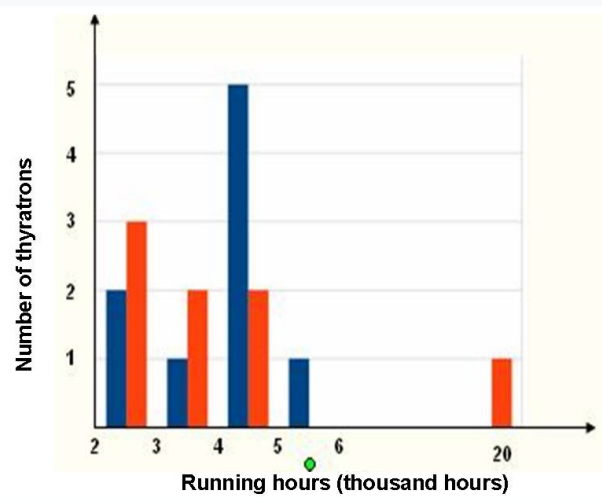

Fig. 9. The operating time of thyratrons CX1525A (blue) and TGI1 2500/50 (red) in accelerator modulators KUT, EPOS, LU-10, (thousand hours) 
Fig. 9 shows the operating time of the main types of thyratrons used in modulators of technological accelerators. Fig. 9 shows that, with proper operation, thyratrons can serve significantly longer than their life.

\section{CONCLUSIONS}

Various modulator elements were modernized for more reliable operation of accelerators. Switch racks were operated in accelerators KUT-1, EPOS, LUE-10, as well as in small accelerators and on test benches. Work was carried out to maintain modulators of technological accelerators in working condition.

The analysis of the work and the comparison of the operational reliability of various types of thyratrons.

For operation in modulators of powerful technological accelerators, the TGI1-2500/50 thyratron was selected. It is reliable in operation, its connection scheme is quite simple. At the moment, thyratrons have worked 4-
6 thousand hours in modulators of technological accelerators.

\section{REFERENCES}

1. V.D. Bochkov, Yu.D. Korolev. Pulse gas-discharge switching devices // Encyclopaedia of low temperature plasma release / V.E. Fortov, Book 4. M.: "Nauka", 2000, p. 446-459.

2. V.D. Bochkov, Yu.D. Dyagilev, Yu.D. Korolev. Powerful switchboards of current with LP of gas // DTE. 1998, № 5, p. 91-95.

3. V.I. Beloglazov, I.A. Chertyshchev, I.A. Chaika, A.I. Kosoi, D.A. Kapliy, V.P. Romasko, V.Yu. Titov, Yu.D. Tur. Design and exploitation powerful thyratron swith in modulators accelerators NSC KIPT // Problems of Atomic Science and Technology. Series "Nuclear Physics Investigations". 2016, № 3, p. 50-53

Article received 18.10.2019

\title{
РАЗРАБОТКА И УСОВЕРШЕНСТВОВАНИЕ КОММУТАЦИОННЫХ СТОЕК ВЫСОКОВОЛЬТНЫХ МОДУЛЯТОРОВ ЛУЭ
}

\author{
В.И. Белоглазов, А.И. Косой, В.А. Мац, В.П. Ромасько, И.А. Чертищев, В.Ю. Титов, И.А. Чайка, \\ Ю.А. Титаренко, Ю.Д. Тур
}

Представлены результаты разработок, эксплуатации и усовершенствований коммутационных стоек. Особое внимание уделено системам контроля и защиты как самих тиратронов, так и управляющих блоков коммутаторов. Проведено сравнение основных характеристик и степени надежности коммутационных стоек и тиратронов различного типа. Проведена разработка и внедрение коммутационных стоек на основе шести типов тиратронов: ТГИ1-1000/25, ТГИ1-2500/35, ТГИ1-5000/50, ТГИ1-5к/50 (Россия), ТГИ1-2500/50 (Украина) и СХ 1525 А (Англия).

\section{РОЗРОБКА І ВДОСКОНАЛЕННЯ КОМУТАЦІЙНИХ СТОЙОК ВИСОКОВОЛЬТНИХ МОДУЛЯТОРІВ ЛПЕ}

\section{В.І. Белоглазов, О.І. Косой, В.О. Мац, В.П. Ромасько, І.О. Чертищев, В.Ю. Титов, І.О. Чайка,} Ю.А. Титаренко, Ю.Д. Тур

Представлено результати розробок, експлуатації та удосконалень комутаційних стойок. Особливу увагу приділено системам контролю і захисту як самих тиратронів, так і управляючих блоків комутаторів. Проведено порівняння основних характеристик і ступеня надійності комутаційних стійок і тиратронів різного типу. Проведена розробка та впровадження комутаційних стойок на основі шести типів тиратронів: ТГІ11000/25, ТГI1-2500/35, ТГІ1-5000/50, ТГІ1-5к/50 (Росія), ТГІ1-2500/50 (Україна) і СХ 1525 А (Англія). 